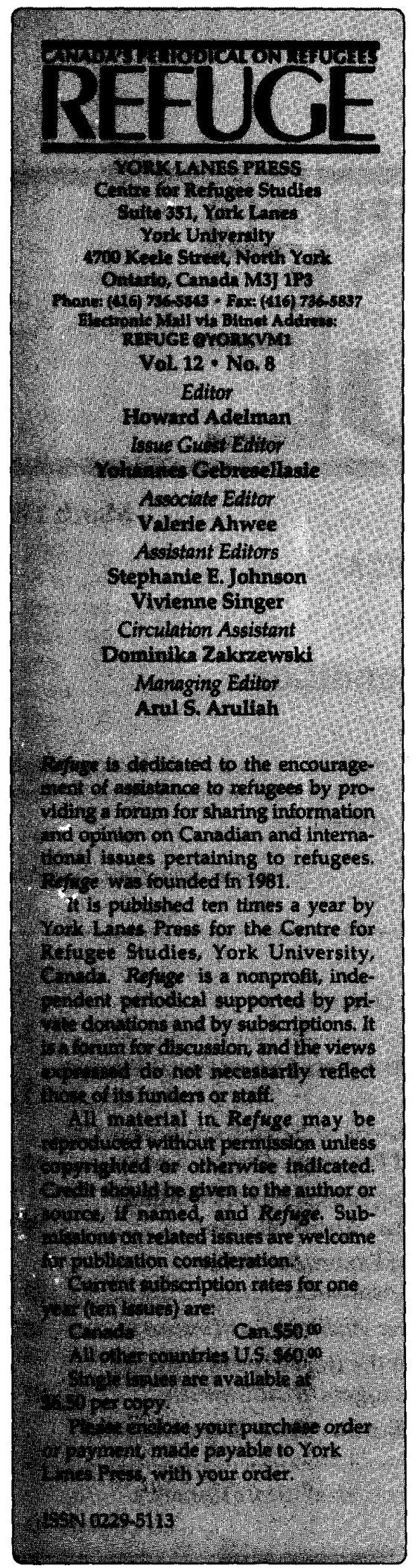

\title{
International Migration in Africa: An Overview
}

\author{
Yohannes Gebresellasie
}

Migration is not a recent phenomenon in Africa; it occupies a significant place in African history that goes back for centuries. Africans migrated before, during and after colonization, regardless of the natural and political obstacles that confronted them.

\section{Factors of Mass Migration}

There are various internal and external socio-economic and political factors that have been responsible for migration in Africa. Some of the internal factors are Africa's adverse socio-economic, political and environmental conditions. For example, the different conflicts, wars and coups based on ethnic, tribal, religious and ideological differences in many African countries (such as Somalia, Ethiopia, Sudan, Liberia, Angola, etc.) have forced millions of Africans to abandon their homeland for safety and security elsewhere. Also, unfavourable environmental conditions have contributed to drought and famine in many African countries, forcing thousands of Africans to leave their home in search of food and shelter elsewhere, mainly in neighbouring countries.

The external factors that have exacerbated migration in Africa include slavery, colonialism and foreign intervention. There are also combinations of internal and external influences. For example, in some African countries, military and autocratic leaders have often been supported by either one or the other of the superpowers receiving assistance to reduce local opposition in return for geo-political strategic benefits. As a result of these oppressive regimes and the support they get from superpowers, thousands of Africans have been forced to abandon their countries. The cases of Ethiopia and Somalia provide typical

Yohannes Gebresellasie, from Laval University, is a research exchange scholar at CRS. examples of the two superpowers playing an important role in supporting oppressive regimes in order to maintain their geo-political strategic interests.

\section{Historic Mass Migrations}

Some of the most important early migrations were "those from India which began before recorded history; the trans-Indian Ocean movements of the present Merina, Betsileo and other ethnic groups of Madagascar, the first probably dating from several centuries B.C. and the most recent from the fifteenth century; the succession of Arab invasions across North Africa and into the Sudan; the general southward movement of various Nilotic and Hametic groups in Eastern Africa and of Bantu groups in Eastern and Southern Africa, the latter forcing the earlier arriving Khoisan and Hottentots into less productive areas; migrations across the Sudan belt and from Equatorial Africa into West Africa, and an opposing trend of nomads coming southward along the steppes south of the Sahara."1 International migration within Africa has been an extension of internal migration. "In most of Sub-Saharan Africa, national frontiers have been comparatively open. Migration across national boundaries, particularly in West Africa, was common prior to independence and the subsequent consolidation of boundaries had a minimal impact, allowing migrants to move freely, unhindered by artificial frontiers." 2

Many tribes in Africa migrated as a result of environmental factors such as drought, overpopulation, overgrazing, etc. For example, in East Africa, "the Luo of Nyanza and Uganda appear to have moved from Eastern Equatorial and part of the Sudan. (The Nilotes most likely had evolved as a distinct group by 1000 A.D.) The Luo people split into two in the migration southwards, one group mov- 
ing east of Lake Nyanza (Victoria) and the other moving west of Lake Nyanza and around the lake to the eastern shore. The Luo arrived at their present location between 1450-1000 A.D."3

Later, during the mercantile period, certain factors, such as the Arab expansion of trade and commerce and the spread of Islam and slavery, increased migration during the precolonial period. Arabs specializing in trade and commerce migrated along the east coast of Africa towards West Africa to expand their trade and commerce and establish trade routes to the Middle East. Islam played a significant role in the early stages of migration in Africa. "With the introduction of Islam in West Africa, a travel route for pilgrims across the continent to Mecca began. Considerable numbers from the stream settled along the route, mainly in the Sudan."4

The Western world and the Arab slave traders forced millions of Africans-particularly those who were young and strong - to leave their countries of origin during the precolonial period. The number of Africans enslaved by Arab and Western slave traders vary according to estimates. For example, "for the trade with the West, figures range from 8 to 20 million with 14 million emigrant slaves being a widely used estimate. ${ }^{5}$ This mass migration of Africans through slavery depopulated Africa and seriously affected agricultural productivity since those who remained behind were mostly the elderly or children.

Generally, in precolonial Africa movements were associated with slavery, trade and commerce, religion, migrant labourers and cash crop farmers. Movements of labourers and cash-crop farmers, particularly in West Africa, began well before the partition of the continent. By the middle of the nineteenth century, in Ghana Akwapem farmers were migrating to unused land where they could grow oil palms-palm products were the leading cash crop of the area at the time. Elsewhere, "many Africans had early developed an adjustment to a form of labour migration." 6

Colonialism had a significant impact on migration patterns in Africa-thou- sands of Africans were displaced. Colonialism also encouraged Europeans and Asians to emigrate to Africa. For example in 1948, "some 40,000 French settled in Algeria. This figure had reached nearly two million by the early 1950 s. In Tunisia, there were about 200,000 Europeans, mostly French at this period, and in Morocco 325,000 ... By the 1960s, nearly 300,000 Europeans had settled in Rhodesia and Zambia, and nearly 100,000 in East Africa." 7 In addition, there were around " 300,000 Asians in East Africa and 621,000 in South Africa." 8

One of the most significant developments in colonial Africa was the emergence of migrant labour as the leading cause of migration. Africa became a competitive market-place among colonial powers for cheap labour and mineral resources. Samir Amin argued, "the colonization and the inclusion of West Africa into close trade with Western Europe led to changes in the economy, and created a large scale labour demand in the coastal regions. This demand led to labour migration and a draining of labour from the hinterland, which seems to have continued."

Although migration has always been an important feature of African history, colonialism changed traditional migration patterns in Africa. As a result, more emphasis was put upon economically motivated movements. Demarcated boundaries made it difficult for groups to migrate freely as they did during the precolonial period. In addition, the colonizers often used forced labour, particularly in the early period of colonization.

\section{Recent Phenomenon}

The problem of migration became acute during colonization and continued to deteriorate even after many African countries achieved their political independence.

The increase in the number of Africans displaced afterindependence is dramatic and explanations for this increase are many and varied. One of the factors

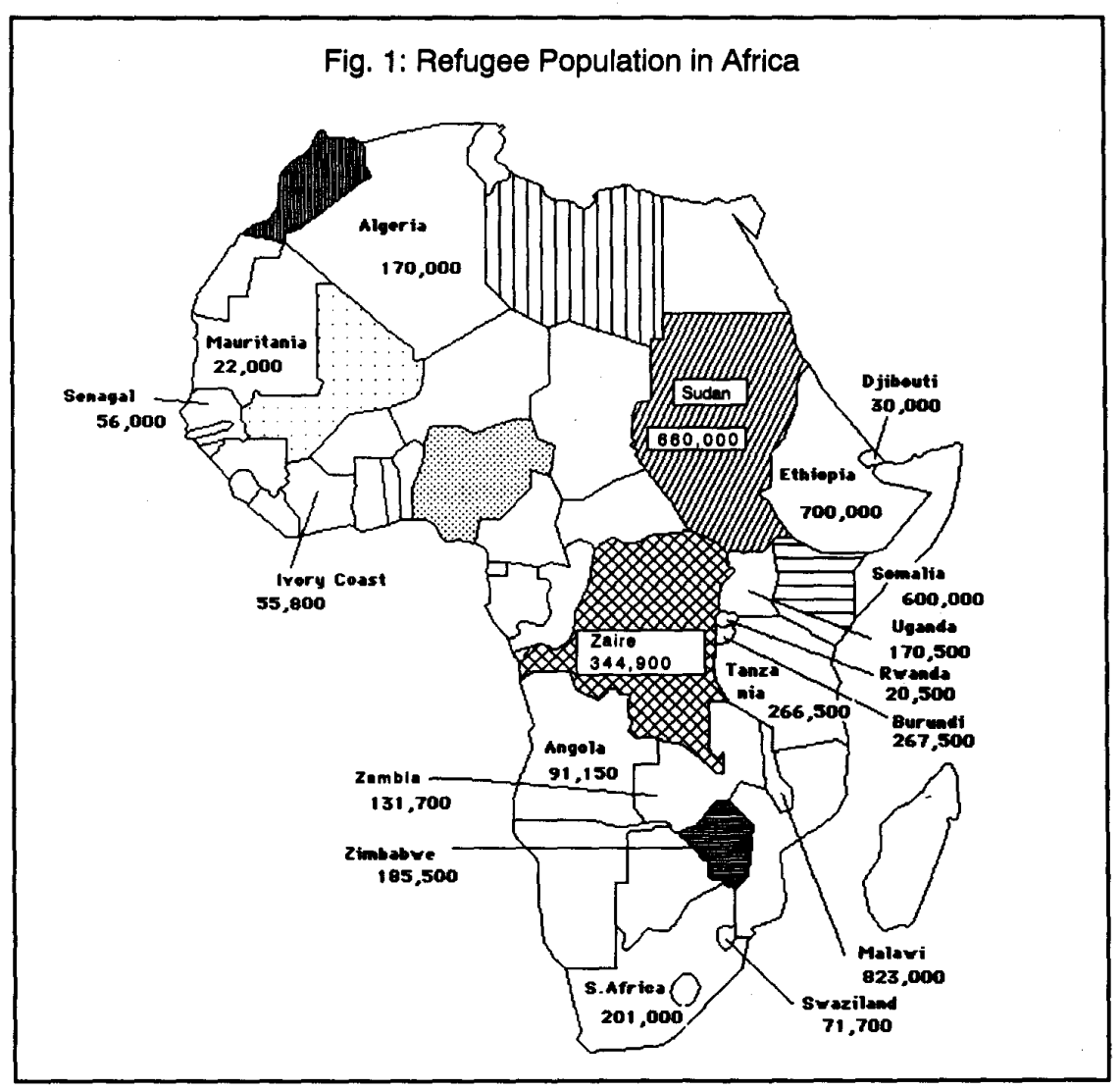

Refuge, Vol. 12, No. 8 (March 1993) 
responsible for the displacement of millions of Africans was the emergence of the new political forces that replaced the former colonial leaders. These new African leaders have been unable to maintain economic, social and political stability in their respective countries. As a result, tribal, ethnic, religious and ideological differences increased. The results were wars and coups in which millions of Africans have been forced to move to regain economic and political stability. This mass exodus forced independent African countries to adopt restrictions to control migration across international boundaries. However, even with such restrictions, there has been a tremendous increase in the number of African migrants and refugees in independent Africa.

Another significant change in migration patterns during the postindependence period was reverse migration and the expulsion of foreigners from some countries in Africa. For example, in West Africa,

Ghana has been a large scale migration area, where migrants have come from $A$ sia,

Lebanon, from the neighbouring African countries. A reverse migration of these people started in 1970, just after the passing of the "compliance order" in Ghana. This law implied that all non-residents should obtain residence permits within 14 days or leave the country. Two hundred thousand people left the country. Many Asians and

Lebanese sold their businesses and left Ghana permanently. ${ }^{10}$

Various incidents of this type occurred in other African countries as well. In Uganda, Idi Amin forced thousands of Ugandan Asians to leave unconditionally; also, in Nigeria, Ghanaians were forced to return to their country due to increasing local hostility towards foreigners.

After independence there was an increase in rural-urban migration because of massive unemployment and economic disparities that still exist in many African countries. There has also been a migration of highly educated Africans to Europe or North America during the postindependence period because they have been unable to find economic and political security in their homelands. Generally, political independence has not solved migration problems facing many African countries. In fact, the problem may have worsened.

\section{Effects of International Migration}

International migration has profound social, economic, political and cultural effects upon migrants, as well as countries of origin and asylum. The following are examples of the effects of international migration.

Demographic: Mass migration increases the local population in places of destination and decreases in places of origin, thus creating negative demographic effects in both places. For example, according to a study done in West Africa (that included Sierra Leone, Gambia, Senegal, Ivory Coast, Upper Volta, Liberia, Ghana, Mali and Togo), whose population in 1975 was forty million,

... the range of population growth rates was from $1.7 \%$ per annum for Upper Volta to $6 \%$ for Ivory Coast. This variation was, however, due much more to migration than to natural increase, as rates of birth and death were very similar from country to country. The total number of foreign nationals living in these countries was 2.8 million in 1975 , or $7 \%$ of the total population. In the Ivory Coast alone, there were 1.43 million foreign nationals, mainly from Upper Volta, Mali and Guinea, out of a total population of about 6.7 million in $1975 .^{11}$

Economic: The economic effect of international migration can be analysed differently depending upon the ideological school of thought. For example, the classical theoreticians argue that migration has a positive impact upon migrants, particularly in the long term, because they become economically better off in their country of destination. This kind of approach generally considers international migration as "an equilibrating response to spatial inequalities, as essentially voluntary in nature, as a rational attempt by migrants to maximize utility and as a vehicle of upward social mobility." 12

The neo-Marxist approach is different. Marxists see international migration as self-destructive. They believe that international migration destroys selfreliance, and promotes dependency and underdevelopment. Marxists regard in- ternational migration as "part of Marx's reserve army of unemployed at the beck and call of capitalist entrepreneurs, and suffering deprivations to sustain the living standards of the indigenous population of the advanced countries."13

Social: Migration breaks family, social, regional and national ties. Migration brings about hardship and grief, particularly when it is forced.

\section{In a society where permanent settlements are the norm, the movement of persons from one place to another results in the severing of most significant social bonds and ties. Emigration entails disruption of the established social structure in the com- munities of origin. But immigration also plays its part by in troducing new and often times conflicting ethnic and cultural ele- ments into the social groups at the place of settlement. Thus migration makes social adjustments inevitable on the part of both the groups losing members and those re- ceiving additions. ${ }^{14}$}

Cultural: The cultural effect of international migration becomes more pronounced when migrants speak different languages or have religions and customs that differ from those of the host population. In many cases, they may be negatively portrayed and considered hostile or threatening. Under such circumstances, they may be required to adjust to a new culture and way of life by ignoring their own culture and traditions.

The assimilation process is not easy either. As long as they live in a new cultural environment, "they have to bear some of the physical and social distinctions of the foreigner, never completely understanding their social surroundings, and are unable to adapt themselves completely to the changing cultural environment." 15

Effect on the Individual: International migration has a tremendous effect on the individual's personality, motivation, creativity, morale and confidence. By moving from one place to another, a person severs most of the bonds that once held him or her to social groups and provided status.

Through migration the individual sheds many social obligations, and in turn is shorn of nearly all the benefits of group association. For his position and status in 
the group and classes of the new community do not come automatically. However, his peace must be determined during a period of trial and testing. The migrant's status in the new community may be vastly different from what it was in the old. Cut adrift from all former and special interest groups, separated from class identification, the individual must gain a place for self in new groups, establish position in the vertical, or class structure of the new community. The migrant abandons the role of "native" and assumes that of "stranger," and the process of becoming accepted, i.e., of gaining a place in a new social grouping, and finding a position in the class system may be neither rapid nor pleasant. . $^{16}$

\section{Similarities and Differences \\ Between Internal and International Migration}

The difference between internal and international migration becameclear when states began defining their boundaries. Now "political and ethnic frontiers are replacing geography as a chief barrier to international migration, thus there is less free international migration than in the past. In Europe, there has been no postwar counterpart to the great influx of workers into France from Italy, Spain and eastern Europe. In Asia, there has been no postwar counterpart migration to Ceylon, Burma and Malaya. In North America, Mexican migration into the United States is more rigidly controlled than in the comparable period of prosperity in the 1920 s." 17

In general, some of the common characteristics of internal and international migration are "the role of spatial inequalities, distance, selectivity, decision making and self-perpetuation. ${ }^{18}$ Their differences are mainly concerning the compartmentalization of the modern world into sovereign states and its effects on the recording of territorial mobility ... The extent of national government intervention and control does add a distinctive dimension to international migration. This dimension has become increasingly dominant in the modern world... Another important difference is the great change in socio-cultural environment involved in moving from one country to another with all the complications, spatial as well as social, for migrants' adaptation and assimilation." 19

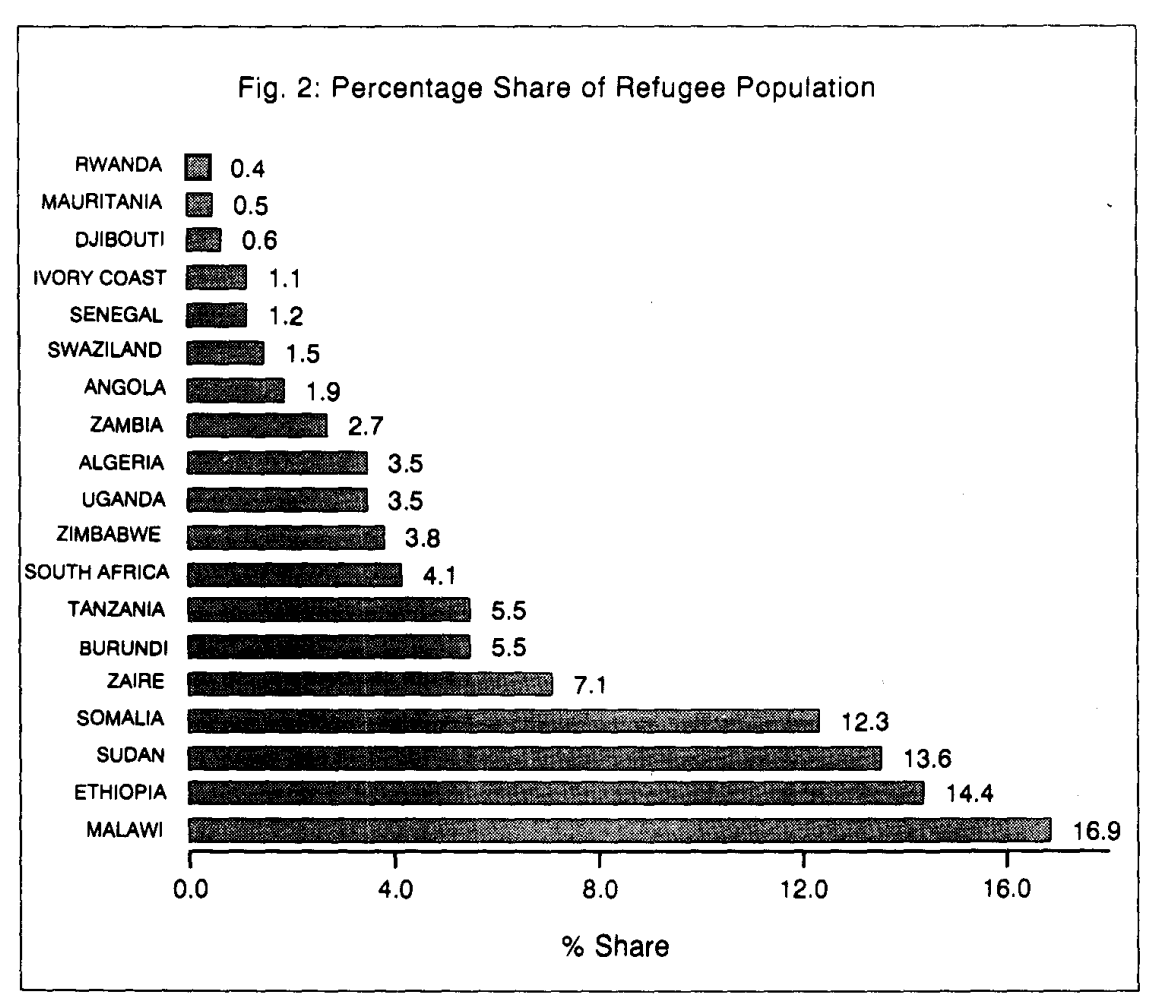

Africa has a history of refugee populations since the 1950s when the first major wave of displaced peoples migrated from Algeria to neighbouring Morocco and Tunisia. The civil wars that followed Sudan's independence in 1956 and Zaire's independence in 1960 brought the refugee problem to central and eastern Africa. As the anticolonial movements gained momentum in Portuguese Africa, the number of displaced Africans exceeded one million in the early 1970 s. $^{20}$

The real problem of refugees in Africa began with the struggle for independence against colonialism in the 1960s. Soon after independence, ethnic, religious and ideological differences brought about numerous conflicts in different countries, which exacerbated refugee movements in Africa. Consequently, "by 1972, out of an estimated population of 323 million people in Africa, over one million were refugees of concern to the United Nations High Commissioner for Refugees." 21

The refugee population continued to increase as conflicts, such as the Nigerian civil war and the Sudanese civil war, in-

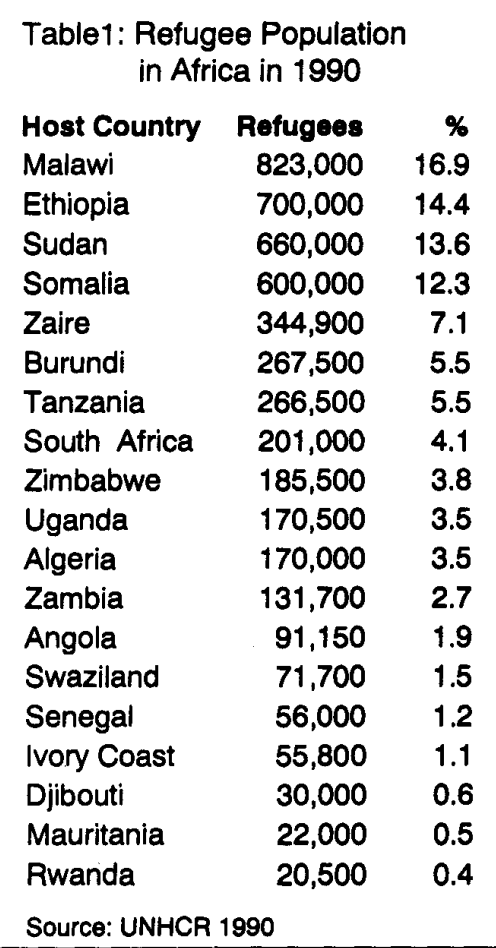

Refuge, Vol. 12, No. 8 (March 1993) 
tensified. "By 1979, it was estimated that the number of refugees had grown to between 3.5 and 4 million; and with the more recent intensification of the Eritrean conflict with Somalia's futile attempt to annex Ogaden, and with renewed disturbances in Uganda, the mid-1982 figure was undoubtedly around the 5 million mark." 22 As illustrated in Table 1 and figures 1 and 2 , nearly five-million refugees were displaced in 1990.

\section{Who Are These Refugees?}

Ces dernièrs années d̀ travers toute l'Afrique, des circonstances se sont produites qui ont contraint des individus et des groupes importants de personnes dquitter leur pays et à traverser les frontières pour rejoindre les pays voisins et parfois même pour aller vivre hors $d$ 'Afrique, d la recherche de la sécurité et d'une vie nouvelle. Parfois ces personnes déplacees ont manifesté leur opposition à des idéologies politiques; elles sont fréquemment divisées pour des raisons ethniques ou tribales. Souvent des conflits entre groupes mettent en danger la vie des individus, détruisant les biens ou imposant des conditions tellement intolérables que l'existence devient impossible et qu'il faut fuir. ${ }^{23}$

The majority of these refugees come from rural areas with little or no education or professional skills. Mass migration often includes entire villages or ethnic groups, most of whom are women and children. Because of their lack of formal education and difficulty in meeting strict selection criteria, African refugees are the least likely to be resettled in industrialized countries. Consequently, the majority of them remain indefinitely in countries of first asylum until conditions in their country of originimprove sufficiently for repatriation.

Most African refugees originate from the Horn of Africa-Somalia, Ethiopia, Sudan and Uganda. Elsewhere in Africa, there are thousands of refugees originating from Mozambique, Liberia and other countries.

African countries that host refugees, such as Ethiopia, Somalia, Sudan and Burundi, are often refugee-producing nations as well. Unfortunately, these countries are also among the world's poorest and are unable to support their own citizens, let alone outsiders. However, even under such circumstances, these host countries have been able to take on the burden of providing asylum to millions of refugees.

\section{Conclusion}

In general then, there are various reasons for international migration in Africa. For example, Aderanti Adepoju argues that "international migration in West Africa is dominated by clandestine or undocumented migration of unskilled persons. In southern Africa migration is temporary and oscillatory, conditioned largely by South African immigration laws. Refugee migration is a major feature in Central and especially East Africa. Clandestine migrations are most frequent among nomads-especially between Somalia, Kenya and Tanzania." ${ }^{24}$

Some of the causes of international migration in Africa are economic while others are social or political. Some causal agents affect the entire clan, tribe or village, while others affect particular regions or individuals. Generally, the reason behind voluntary migration may be economic, while that of forced migration is political. There are various other factors as well. As Milward and Saul put it,

the key question is one of motive, for migration was rarely accomplished without anguish and hardship and the benefits were most often reaped only by the succeeding generations. Some went because the economic situationat homewashopeless, some because the chance of getting land somewhere offered greater opportunities to them and their families. Some sought new opportunities, some went to avoid change ... Some went to escape military services, some disliked taxes and the insolence of officials. Some went overseas in search of greater political and religious freedom ... Some were paid to go. Some went for the adventure ... At times, it became almost a fever, an irrational frenzy. ${ }^{25}$

\section{Notes}

1. Aderanti Adepojo, "International Migration in Africa South of the Sahara," International Migration Today 1 (1988): 78.

2. William Hance, Population Migration and Urbanization in Africa (New York, New York: Columbia University Press, 1970).
3. International Migration Policies and Programs, A World Survey (New York, New York: Department of International Economic and Social Affairs, 1982):68.

4. Scandinavian Institute of African Studies, A Demographic Analysis of East Africa: $A$ Sociological Interpretation (Uppsala, Sweden: Scandinavian Institute of African Studies, 1978): 140.

5. W.T.S. Gould, "International Migration in Tropical Africa," International Migration Review 8, no. 3 (1974): 347-65.

6. Hance, Population, Migration, Urbanization in Africa, 129.

7. Ibid., 130.

8. John Richard, Africa: A Study of Geography for Advanced Students (Burnt Mill, Harlow, Essex: Longman Group Ltd., 1979): 62 .

9. Ibid., 6.

10. Monsted Mette and Walji Parveen, $A$ Demographic Analysis of East Africa: $A$ Sociological Interpretation (Uppsala, Sweden: Scandinavian Institute of African Studies, 1978): 141.

11. Ibid., 144

12. Philip Ogaden, Migration and Geographical Change (Cambridge, England: Cambridge University Press, 1984): 35.

13. R. Jones, A Population Geography (New York, New York: Harper and Row Publishers, 1983): 278.

14. Ibid., 278.

15. Lynn Smith, Population Analysis (New York, New York: McGraw Hill Publication Ind., 1948): 292.

16. Ibid., 293.

17. Ibid.

18. Jones, A Population Geography, 252.

19. Ibid., 22

20. John Clarke, Mustafa Khogali and Leszel Kosinski, Population and Development Projects in Africa (Cambridge, England: Cambridge University Press, 1985), 68.

21. Louise Holborn, Refugees: A Problem of Our Time-The Work of the United Nations High Commissioner for Refugees, 19511972, Vol. 11 (Meluchen, New Jersey: Louise Holborn, 1975): 825.

22. Clarke, Khogali and Kosinski, Population and Development Projects in Africa, 69.

23. "L'Afrique et ces refugies," Le Journal des refugies africains (Juine 20, 1975): 13.

24. Adepojo, "International Migration in Africa South of the Sahara," 78.

25. Ogaden, Migration and Geographical Change, 35. 